\title{
Relationships between burnout and role ambiguity, role conflict and employee absenteeism among health workers
}

\section{Burnout y su relación con la ambigüedad de rol, conflicto de rol y absentismo laboral en trabajadores de la salud}

\author{
Víctor E. Olivares-Faúndez \\ Escuela de Psicología, Universidad de Santiago de Chile, Chile \\ Pedro R. Gil-Monte \\ UNIPSICO, Universidad de Valencia, España \\ Luis Mena \\ Escuela de Psicología, Universidad de Santiago de Chile, Chile \\ Carolina Jélvez-Wilke \\ Escuela de Psicología, Universidad de Santiago de Chile, Chile \\ Hugo Figueiredo-Ferraz \\ UNIPSICO, Universidad de Valencia, España
}

Rec (19 de Junio de 2013) Acept (28 de Abril de 2014)

\section{Resumen}

\begin{abstract}
El objetivo de esta investigación fue analizar la influencia de algunos factores de riesgo psicosociales en el desarrollo del burnout y analizar la influencia de este fenómeno en el absentismo laboral. La muestra la integraron 142 trabajadores de la salud. El análisis de los datos se efectuó considerando estadística descriptiva y modelos de regresión lineal múltiple. Los resultados confirman la influencia de la ambigüedad y del conflicto de rol sobre el Burnout $[\mathrm{F}(2.139)=26.720 ; \mathrm{p}<.001]$ y no se valida la influencia de éste sobre el absentismo laboral. No obstante, se evidencia una relación significativa y positiva entre la dimensión desgate psíquico y absentismo laboral $(\beta=0.197 ; \mathrm{p}<.05)$. Se concluye que el conflicto de rol es el predictor más intenso del componente emocional del burnout (desgaste psíquico; $\beta=0.585 ; \mathrm{p}<.001$ ). Se evidencia que un esfuerzo emocional sostenido pudiese favorecer el absentismo laboral.

Palabras clave: psicología de la salud, burnout, ambigüedad, conflicto de rol y absentismo laboral.
\end{abstract}

\section{Abstract}

The aim of this research was to analyze the influence of some psychosocial risk factors in the development of burnout and to analyze the influence of this phenomenon on employee absenteeism. The study sample included 142 health care workers. The data analysis included descriptive statistics and multiple linear regression models. The results confirmed the influence of role ambiguity and role conflict on burnout [F (2.139) $=26.720 ; \mathrm{p}<.001 \mathrm{]}$, but the influence of burnout on employee absenteeism was not confirmed. However, a significant and positive relationship has been shown between burnout and employee absenteeism $(\beta=0.197$; $\mathrm{p}<.05$ ). In conclusion, the findings of this study support the claims that role conflict is a more intense predictor of the emotional component of burnout (burnout; $\beta=0.585 ; \mathrm{p}<.001$ ). Additionally, there is evidence that prolonged emotional strain could encourage employee absenteeism.

Keywords: health psychology, burnout, role ambiguity and conflict and employee absenteeism.

Correspondencia:

Escuela de Psicología, Universidad de Santiago de Chile, USACH. Avda. Ecuador \# 3650, 3 Piso, Santiago. E- mail: victor.olivares.f@usach.cl, luis. mena@usach.cl,jelvezw@gmail.com

Facultad de Psicología (Dep. Social), Universidad de Valencia, España. Avda. Blasco Ibáñez, 21; 46010 Valencia. Tel: +34-963864564, Fax: +34-963864668, e-mail: pedro.gil-monte@uv.es, hufidema@postal.uv.es

Pedro R. Gil-Monte and Hugo Figueiredo-Ferraz were supported by the Ministerio de Economía y Competividad (MINECO) (Spanish Government), Grant: PSI2013-48185-R. 


\section{Introduction}

The technological revolution in which we are immersed has been regarded as the transformation of productive, cultural and organizational systems, creating a new economic system characterized by market globalization (Gil-Monte, 2005). This has brought about prolonged work days with deleterious effects (Levey, 2001), an increase in emotional and cognitive work, demands for greater quality and breach of the psychological contract, principle threats to psychological well-being and the primary cause of chronic work stress (Moreno-Jiménez \& Garrosa, 2009), which has increased considerably (Maslach, 2003), and in the future is likely to become an urgent social problem (Shirom, 2009).

Many organizations currently have very long and/or irregular shifts, which have significant effects on workers' physical and mental health (Amelsvoort, 2004), an issue that has been linked to burnout in some relevant studies Honkonen et al., 2006; Gregersen, Kuhnert, Zimber \& Nienhaus, 2010). This condition is especially important to consider in health workers, a group particularly vulnerable to suffering disorders derived from these conditions (Berger \& Hobbs, 2006; Olson, Drage \& Auger, 2009; Rauchenzauner, et al., 2009).

Although there is no a single definition of burnout, there is a broad consensus that it is an individual's response to chronic work stress (Cooper, Dewe \& O'Driscoll, 2001; Jenaro, Flores \& Arias, 2007; Maslach, Schaufeli \& Leiter, 2001). It is an internal subjective experience that groups feelings and attitudes and that is negative for people and organizations, given that it can result in alterations, problems and psychophysiological dysfunctions (Gil-Monte, 2005).

Throughout the study of burnout, many organizational and personal variables have been proposed as antecedents and consequences of this phenomenon. Role conflict and role ambiguity have been identified as relevant predictors (Collins, 2000; Lee \& Ashforth, 1996) and employee absenteeism as an important consequence (Schaufeli, Bakker \& Van Rhenen, 2009).

Over the years role conflict and role ambiguity have been identified as important causes of stress in the workplace (Lambert \& Lambert, 2001). To date, many studies have identified the demands of role as burnout antecedents (Kokkinos, 2007; Peeters, Montgomery, Bakker \& Schaufeli, 2005), since both role conflict and role ambiguity have been positively associated with this occurrence (Collins, 2000; Papastylianou, Kaila \& Polychronopoulos, 2009; Schaufeli, Bakker, Heijden \& Prins, 2009; Tunc \& Kutanis, 2009). Role conflict is defined as the incongruity of expectations associated with a role (Kahn, Wolfe, Quinn, Snoek \& Rosenthal, 1964); this can also be experienced when a person is expected to behave in a way that violates their personal values (Brewer \& Clippard, 2002). There are many studies that show a positive relationship between role conflict and burnout (Lepine, Podsakoff \& Lepine, 2005; Lee \& Ashforth, 1996; Peeters et al., 2005; Schaufeli, 2007). Role ambiguity is the degree to which clear information does not relate to the expectation associated with a role (Kahn et al., 1964). Many studies show a positive relationship between role ambiguity and burnout (Collins, 2000; Kokkinos, 2007; Shinan-Altman \& Cohen, 2010). The scientific results have indicated to date that role conflict is the most intense predictor of the emotional component of the syndrome (emotional exhaustion) (Jawahar, Stone \& Kisamore, 2007; Lee \& Ashforth, 1996; Piko, 2006; Posig \& Kickul, 2003; Mohr \& Puck, 2007), whereas role ambiguity is the most intense predictor of the cognitive component (low personal accomplishment) (Gil-Monte, 2005; Örtqvist \& Wincent, 2006). These phenomena are included in different comprehensive models of the syndrome (Posig \& Kickul, 2003; Shinan-Altman \& Cohen, 2010; Radha, 2007), which indicate the importance of these stressors in the development of burnout.

Related to the consequences, some studies conclude that between $50 \%$ and $60 \%$ of employee absenteeism is caused by work stress (Cox, Griffiths \& Rial-González, 2000), which according to Hochwälder, Bergsten-Brucefors (2005) may involve $2 \%$ of health professionals, a concept defined by the International Labor Organization (ILO, 1991) as non-attendance at work by an employee during a normally scheduled work period, excluding vacation periods, strikes and sick leave attributable to an individual's incapacity, with the exception of pregnancy or imprisonment.

Important investigations have related the presence of burnout to increased employee absenteeism rates (Iverson, Olekalns \& Erwin, 1998; Parker \& Kulik, 1995; Schaufeli et al., 2009), and statistically significant associations have also been observed between the dimensions of the Maslach Burnout Inventory (MBI) and employee absenteeism (Bekker, Croon \& Bresers, 2005; Iverson et al., 1998; Petitta \& Vecchione, 2011; Toppinen-Tanner, Ojajärvi, Väänänen, Kalimo \& Jäppinen, 2005). These results are similar to those found by Gil-Monte (2002), who after using the Spanish Burnout Inventory (SBI) ${ }^{1}$ reported that its dimensions were significantly associated with absenteeism attitudes and

\footnotetext{
The Spanish name of the questionnaire "Spanish Burnout Inventory" (SBI) is: "Cuestionario para la Evaluación del Síndrome de Quemarse por el Trabajo" (CESQT).
} 
behaviors. These findings generally do not explain more of than $2 \%$ of the absenteeism variance (Bakker,

Demerouti, Taris, Schaufeli \& Shreurs, 2003). It should be emphasized that burnout, when considered with the MBI, particularly with the dimension emotional exhaustion, presents significant positive relationships with the worker's intentions to leave the organization (Bakker, Le Blanc \& Schaufeli, 2005; Glazer, 2005; Petitta \& Vecchione, 2011).

According to Gil-Monte (Gil-Monte, 2012; Gil-Monte, Peiró \& Valcárcel, 1998) burnout progresses in parallel from cognitive deterioration (i.e., low Enthusiasm towards the job or low personal accomplishment ) and emotional deterioration (i.e., psychological or emotional exhaustion), to an attitudinal deterioration in the form of cynicism, indolence or indifference towards the people the professional must serve, dysfunctional aspects that generate coping strategies (Taris, Le Blanc, Schaufeli \& Schreurs, 2005) after a re-evaluation stage. This approach considers the model of attitudes and change developed by Eagly and Chaiken (1993), which integrates the role of cognitive and emotional experiences as mediators in the relationship between perceived work stress and results of behavior/attitude. Furthermore, the model considers that, in some cases, negative attitudes in the workplace, in special towards the people with whom the worker has working relationships, lead to feelings of guilt (Gil-Monte, 2012). Having guilt feelings is a variable apparently involved in burnout (Ekstedt \& Fagerberg, 2005; Maslach, 1982; Price \& Murphy, 1984). This variable could explain the different types of burnout (Farber, 2000; Paine, 1982; Vanheule, Lievrouw \& Verhaeghe, 2003; Tops et al., 2007), taking into account the role of guilt feelings in the relationship between burnout and its consequences (GilMonte, 2005). Guilt is conceptualized as a disagreeable feeling associated with remorse after the recognition that a moral norm has been violated, or may be violated, in contrast to shame, where the focus is on the person's negative evaluation of themselves; guilt involves a negative assessment of a specific behavior (Tangney, Stuewig \& Mashek, 2007). From an interpersonal approach (Baumeister, Stillwell \& Heatherton, 1994), guilt is described as a social emotion linked to communal relationships. It is highly ingrained in two basic affective reactions: empathic activation, and anxiety of rejection by others. Baumeister et al. (1994) consider that guilt makes it possible to alleviate the distress produced by the imbalance in the emotional states resulting from social exchanges. Guilt has pro-social effects, since it motivates people to make peace with others, whereas excessive or inappropriate levels of guilt can produce a dysfunctional and destructive experience and in some cases psychological effects and somatization symptoms (Pineles, Street \& Koenen, 2006).

The SBI (Gil-Monte, Figueiredo-Ferraz \& Valdez, 2013; Gil-Monte \& Olivares, 2011) evaluates these four aspects of burnout: Enthusiasm towards the job, Psychological exhaustion, Indolence and Feelings of guilt. According to the SBI, low scores in Enthusiasm towards the job combined with high scores in Psychological exhaustion and Indolence indicate high levels of burnout. The theoretical model that underpins the SBI describes two profiles in the development of the syndrome. The attitudes and behaviors of indolence can be seen as a coping mechanism to treat cognitive (i.e., low Enthusiasm towards the job) and emotional (i.e., Psychological exhaustion) deterioration. Nevertheless, whereas for some professionals this coping strategy allows them to control their stress levels (Profile 1), other professionals feel uncomfortable with them and develop greater feelings of guilt, producing the most serious manifestations of the syndrome and health-related disorders (Profile 2) (Gil-Monte, 2005; 2012).

The aims of this study were to analyze the influence of work stressors, role ambiguity and role conflict on the development of burnout in a sample of health workers exposed to prolonged work days (shifts), and to analyze the influence of burnout on employee absenteeism. It is expected that role ambiguity is a significant predictor of burnout because the levels of role ambiguity will be significantly and positively associated with the syndrome levels (Hypothesis 1) and role conflict is a significant predictor of burnout because the levels of role conflict will be associated positively and significantly with the syndrome levels (Hypothesis 2). It is also expected that burnout is an important predictor of employee absenteeism because the levels of the syndrome will be significantly and positively associated with employee absenteeism levels (Hypothesis 3).

\section{Method}

\section{Participants}

The sample was comprised of 142 workers at a large hospital in Chile. Non-randomized sampling was used to distribute 178 questionnaires in 5 different work units within the organization. The response rate for the study was $79.75 \%$. With regard to gender, $27.5 \%(\mathrm{n}=39)$ participants were men and $72.5 \%(\mathrm{n}=103)$ were women. The mean age of the group was 37.44 years (range 20-62, SD 8.827). $70.4 \%(n=$ 
100) were in a stable couple relationship and $29.6 \%(n=42)$ were not. In terms of the type of contract, $54.9 \%(\mathrm{n}=78)$ of the sample had a temporary contract (one year), $31 \%(\mathrm{n}=$ 44) were tenure and $14.1 \%(\mathrm{n}=20)$ had an hourly contract (wages for hours worked). The mean number of years at work was 12.20 years (SD 8.51 years) and as employees at the hospital 9.87 years (SD 8.62 years). In terms of the professional category in which the study participants were distributed, $49.3 \%(\mathrm{n}=70)$ were technical workers, $17.6 \%$ $(\mathrm{n}=25)$ were orderlies, $16.9 \%(\mathrm{n}=24)$ were nurses, $12 \%$ $(\mathrm{n}=17)$ physicians, $3.5 \%(\mathrm{n}=5)$ preschool teachers and $0.7 \%$ $(\mathrm{n}=1)$ physiotherapists.

\section{Instruments}

Role conflict was measured using the subscale UNIPSICO (5 items, $\alpha=.67$ ), a version adapted from the scale created by Rizzo, House and Lirtzman (1970), valued with a 5-point scale, from 0 "Never" to 4 "Very frequently: every day". The items refer to the existence of demands in the workplace incompatible with each other or unviable (e.g., I am asked to perform functions and tasks for which I am not authorized). Role ambiguity was measured using the subscale UNIPSICO (Figueiredo-Ferraz, Gil-Monte, GrauAlberola, Llorca-Pellicer \& García-Juesas) (5 items, $\alpha=$ .67), a version adapted from the scale created by Rizzo, House and Lirtzman (1970), valued with a 5-point scale, from 0 "Never" to 4 "Very frequently: every day". The items deal with knowledge of the attributions and competencies, objectives, tasks, responsibilities and content of the job, as well as how to do it and what it is expected of the worker (e.g., I know exactly what it is expected of me at work).

Burnout was measured using the SBI (Gil-Monte et al., 2013; Gil-Monte \& Olivares, 2011). This instrument is comprised of 20 items distributed into four: Enthusiasm towards the job (5 items) (e.g., I see my work as a source of personal accomplishment.) $(\alpha=.82)$; Psychological exhaustion (4 items) (e.g., I feel overwhelmed by the work) ( $\alpha=.83$ ); Indolence (6 items) (e.g., I don't like taking care of some patients $\alpha=.59$ ); and Guilt (5 items) (e.g., I feel guilty about some of my attitudes at work) $(\alpha=.81)$. The items are evaluated on a 5-point frequency scale that goes from 0 "Never" to 4 "Very frequently: every day". Low scores in Enthusiasm towards the job combined with high scores in Psychological exhaustion and Indolence establish the presence of the syndrome (Profile 1), which when associated with high levels of Guilt often indicates a more serious problem that might identify those clinical cases most exacerbated by burnout (Profile 2).
Employee absenteeism (Figueiredo-Ferraz et al., 2013) was evaluated by means of a specifically created five-point item: from 0 "Never" to 4, "Very frequently: every day" (UNIPSICO) ("I have been absent for reasons associated with work stress this year"), added to the battery of tests used in the present study.

\section{Procedure}

For data collection, first the General Directorate of the hospital was contacted and the aim of the study explained in order to obtain the necessary authorization and support to apply the instruments. This study was approved by the institution's Ethics Committee, where the rigor and quality of the study was verified from the point of view of its suitability and ethical viability. All the participants who responded to the questionnaire did so voluntarily and anonymously after reading and accepting the informed consent. Participants were then selected on a non-random basis. The questionnaires were applied in all the collaborating work units after approval by the head of each unit, being completed manually on paper during each shift. The data were analyzed with SPSS v. 21.

\section{Results}

In terms of the values of the internal consistencies, means, standard deviations and skewness of the scales and subscales of burnout and of those that comprise role dysfunctions and employee absenteeism, these were generally within adequate parameters.

In general, the Cronbach's alpha values were satisfactory for three of the scales used with values higher than .70 (Nunnaly, 1978), although the role conflict $(\alpha=.67)$ and role ambiguity $(\alpha=.60)$ values were moderately low. It should be noted that the indolence values were the lowest on the scales $(\alpha=.59)$.

The means of the scales fluctuated between 1.23 (burnout) and 3.41 (role ambiguity), with the variation in the standard deviations being between 0.56 (employee absenteeism) and 1.07 (role conflict).

Conversely, the skewness values of the burnout scales fluctuated between -0.93 and 0.29 , with role ambiguity and role conflict scales being -0.97 and -0.23 , respectively. It should be noted that the skewness value of the employee absenteeism scale was 1.91 , a value outside the $+/-1$ range.

In terms of the correlation analyses, the results indicate the existence of statistically significant and positive 
relationships between role conflict and burnout $(\mathrm{r}=.53 ; \mathrm{p}$ $<.001$ ), and between role conflict and the dimensions psychological exhaustion $(\mathrm{r}=.47 ; \mathrm{p}<.001)$ and between role conflict and indolence $(\mathrm{r}=.42 ; \mathrm{p}<.001)$. On the other hand, the correlation analyses of the variable employee absenteeism did not establish significant relationships with burnout $(\mathrm{r}=.12$; $\mathrm{p}>.05$ ), yet the results indicate the existence of statistically significant and positive relationships between employee absenteeism and the dimension psychological exhaustion $(\mathrm{r}=.21$; $\mathrm{p}<.05$ ). A subsequent multiple regression analysis stepwise was performed to determine whether role ambiguity and role conflict influence or can predict burnout and the dimensions enthusiasm towards the job, psychological exhaustion and indolence. Table 1 shows the results of the regression equation of the aforementioned variables. In the first regression equation, taking burnout as the criterion variable, the block of role conflict and role ambiguity is significant [F (2.139) $=26.720 ; \mathrm{p}<.001$ ], explaining $27.8 \%$ of the variance, and it can be seen how role conflict $(\beta=.334 ; \mathrm{p}<.001)$ and role ambiguity $(\beta=-.152 ; p<.05)$ are related significantly to burnout and in the expected direction.

In the second block, the burnout sub-dimension enthusiasm towards the job is taken as the criterion variable, the block of role conflict and role ambiguity is significant [F $(2.139)=7.237 ; \mathrm{p}<.01]$ and explains $94 \%$ of the variance, and it can be seen how role conflict $(\beta=-.158 ; \mathrm{p}<.01)$ and role ambiguity $(\beta=.269 ; \mathrm{p}<.05)$ are related significantly with the dimension enthusiasm towards the job and in the expected direction.

In the third block, the burnout sub-dimension psychological exhaustion is taken as the criterion variable, the block of role conflict and role ambiguity is significant [F (2.139) $=23.047 ; \mathrm{p}<.001]$ and explains $24.9 \%$ of the variance, and it can be seen how role conflict $(\beta=.585 ; \mathrm{p}<.001)$ is related significantly with the dimension and in the expected direction; nevertheless, role ambiguity is not significantly related to the dimension psychological exhaustion $(\beta=$ $-0.101 ; \mathrm{p}>.05)$.

In the fourth block, the burnout sub-dimension indolence is taken as the criterion variable, the block of role conflict and role ambiguity is significant $[\mathrm{F}(2.139)=17.237$; $\mathrm{p}<$ $.01]$ and explains $20.4 \%$ of the variance, and it can be seen how role conflict $(\beta=.289 ; \mathrm{p}<.001)$ and role ambiguity $(\beta$ $=-.173 ; \mathrm{p}<.01)$ are related significantly with the dimension indolence and in the expected direction.

Table 1. Regression equation stepwise to predict burnout and its dimensions.

\begin{tabular}{llll}
\hline & $\beta$ & $\mathrm{R}^{2}$ & $\mathrm{~F}$ \\
\hline 1. DV: BURNOUT & & $.278^{* * *}$ & $26.720^{* * *}$ \\
Role conflict & $.334^{* * *}$ & & \\
Role ambiguity & $-.152^{*}$ & & $7.237^{* *}$ \\
2. DV: ENTHUSIASM FOR THE JOB & & $.94^{* *}$ & $23.047^{* * *}$ \\
Role conflict & $-.158^{* *}$ & & $.249^{* * *}$ \\
Role ambiguity & $.269^{*}$ & & $17.848^{* * *}$ \\
3. DV: PSYCHOLOGICAL EXHAUSTION & & $.204^{* * *}$ \\
Role conflict & $.585^{* * *}$ & \\
4. DV: INDOLENCE & & \\
Role conflict & $.289^{* * *}$ & \\
Role ambiguity & $-.173^{* *}$ & & \\
\hline
\end{tabular}

$* \mathrm{p}<.05, * * \mathrm{p}<.01, * * * \mathrm{p}<.001$ 
116 Víctor E. Olivares-Faúndez, Pedro R. Gil-Monte, Luis Mena, Carolina Jélvez-Wilke, Hugo Figueiredo-Ferraz

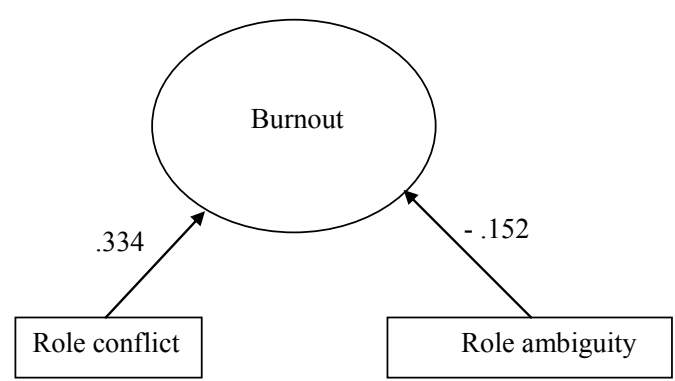

Figure 1. Burnout level predictors.

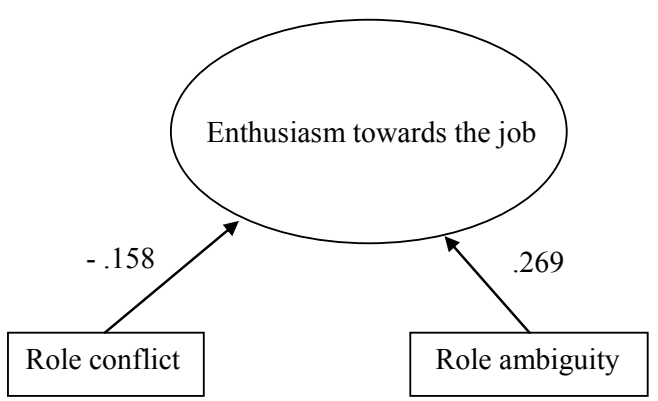

Figure 2. Predictor of dimension Enthusiasm towards the job

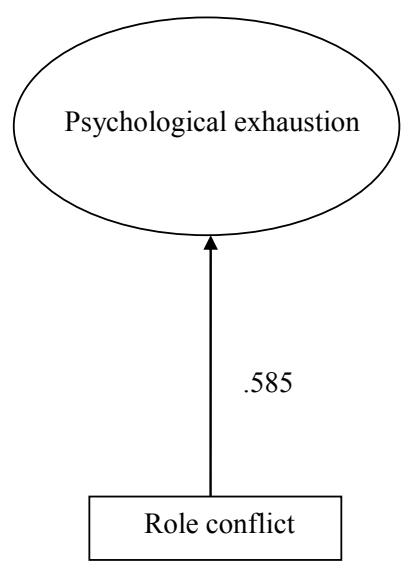

Figure 3. Predictor of the dimension Psychological exhaustion.

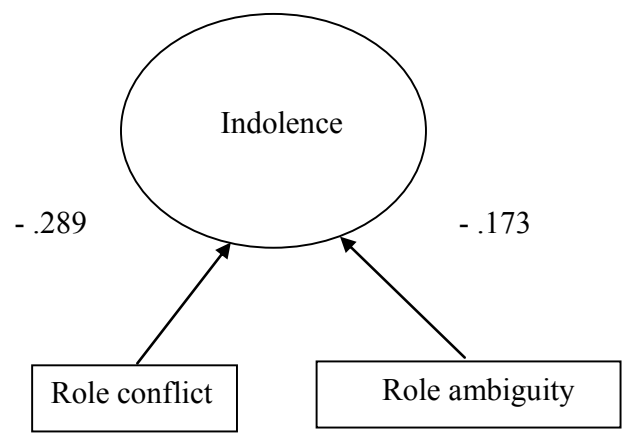

Figure 4. Predictor of the dimension Enthusiasm for the job. 
Table 2. Equation stepwise to predict employee absenteeism.

\begin{tabular}{lccc}
\hline & $\beta$ & $\mathrm{R}^{2}$ & $\mathrm{~F}$ \\
\hline $\begin{array}{l}\text { DV: EMPLOYEE ABSENTEEISM } \\
\text { Psychological Exhaustion }\end{array}$ & & & \\
\hline
\end{tabular}

$* \mathrm{p}<.05$

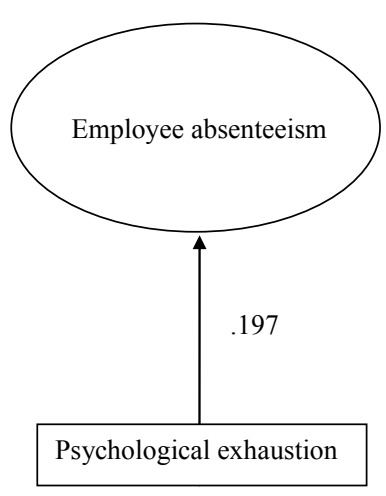

Figure 5. Predictors of Employee absenteeism.

A bivariate regression analysis was also performed to determine if employee absenteeism is an antecedent or predictor variable of burnout (Table 2). The results showed that the relationship is not significant [F (1.140) =.949; $\mathrm{p}>.05$ ], and therefore burnout may not be a variable associated with employee absenteeism. Nevertheless, the bivariate regressions with the dimensions of burnout revealed a significant and positive relationship between employee absenteeism and the dimension psychological exhaustion $(\beta=0.197$; $p$ $<.05)$. Therefore, it is possible to observe that the variable employee absenteeism is influenced significantly by the variable psychological exhaustion.

\section{Discussion}

In terms of the study aims, Hypothesis 1 is confirmed because role ambiguity, measured as role clarity, is a significant predictor of burnout, and this is because the syndrome is negatively and significantly associated with role ambiguity levels $(\beta=-.173 ; \mathrm{p}<.01)$. These results are consistent with studies conducted on health samples, as well as other occupational groups, such as Spanish soldiers (López, Osca \& Rodríguez 2008) and other groups (Collins, 2000; Zellars, Perrewé \& Hochwarter, 1999). In agreement with the literature, these results reflect that role ambiguity evokes a cognitive-attitudinal response (indolence) and that it is an intense predictor of both components of the syndrome.

Hypothesis 2 is also confirmed, given that role conflict is a significant predictor of burnout, because the syndrome levels are significantly and positively associated with role conflict levels $(\beta=.289 ; \mathrm{p}<.001)$. These results are supported by the studies by Osca, González-Camino, Bardera \& Peiró (2003), Jawahar et al., (2007) and Zellars et al. (1999) conducted on foreign samples.

Additionally, statistically significant and positive relationships are also found with the dimensions enthusiasm towards the job $(\mathrm{r}=.21 ; \mathrm{p}<.05)$ and indolence $(\mathrm{r}=.42 ; \mathrm{p}$ $<.001)$ and more strongly with psychological exhaustion ( $\mathrm{r}$ $=0.47 ; \mathrm{p}<.001$ ), which is because, apparently, role conflict is the most intense predictor of the emotional component of burnout, which is consistent with what has been reported by some important authors (Gil-Monte, Valcárcel \& Zornoza, 1995; Iverson et al., 1998). These results have empirical support in the study by Jawahar et al. (2007).

In conclusion we can say that both role ambiguity and role conflict influence burnout $[\mathrm{F}(2.139)=26.720 ; \mathrm{p}<$ .001 ], explaining $27.8 \%$ of the variance, and it can be seen that role conflict $(\beta=.334 ; \mathrm{p}<.001)$ and role ambiguity $(\beta$ $=-.152 ; \mathrm{p}<.05)$ are related significantly with burnout and in the expected direction, but that the best predictor of the syndrome is role conflict.

In terms of the influence of burnout on employee absenteeism, Hypothesis 3 is not confirmed and therefore the null hypothesis is approved, because burnout in this study is not associated with employee absenteeism; however, a significant and positive relationship was demonstrated between psychological exhaustion and employee absenteeism $(\mathrm{r}=0.21 ; \mathrm{p}<.05)$. These results are supported by some studies of samples of nurses (Firth and Britton, 1989) and 
teachers (Schwab, Jackson \& Schuler, 1986). Consistent with the literature, employee absenteeism is understood as a reaction to stress in the workplace when one is unable to confront the imposed demands; yet in this case, it may be due to a reaction against psychological exhaustion as this does influence absenteeism $(\beta=0.197 ; \mathrm{p}<.05)$, explaining $43 \%$ of the variance. This impact could occur as a result of the intense emotional effort public sector workers make because those in the service sector and above all in the health sector must offer emotional support to the people in their care, providing an empathetic relationship that on many occasions is imposed or turns into a friendship, which causes the worker to become even more involved with the patient and therefore suffer more from exhaustion (Gil-Monte, 2005) during extensive and arduous working periods. However, and because this relation has not been studied in Chilean health samples, the results must be viewed with reserve and future research in this line is warranted.

Given the consequences that burnout has on the individuals, the organization where they work, and on those receiving these workers' services, it is important that measures be taken to prevent it and/or treat with it. In light of the results presented here, intervention at the individual, group and organizational levels is recommended. At the individual level, the health professional must be aware of the cognitive processes of self-evaluation that lead to the onset of burnout, and must be familiar with and develop strategies to eliminate the underlying sources of stress. As inferred in the study results, burnout begins with symptoms which are cognitive in nature, such as seeing problems in everything, insecurity, reinforcement of feelings such as disillusion or nervousness, which in turn promote negative thoughts. It is possible that if the dysfunctional and non-adaptive thoughts are eliminated, the negative emotions will also disappear, thus avoiding the emergence of the attitudes of indolence that characterize the more advanced phases of this syndrome. To deal with these symptoms (feeling incapable, contrariness, thinking you work badly...), professionals can acquire or improve their individual coping strategies through e.g. further education programs, problem-solving or assertiveness training.

It must be borne in mind that due to the sample size of the study it would be advisable to obtain descriptive values for the dimensions with larger samples and differentiating in terms of sociodemographic variables, such as gender or age. As recommendations to continue working in the theoretical and applied line of the SBI model, it is necessary to conduct studies that replicate the results obtained with workers from different occupational groups in different countries and different sociocultural contexts. A second line of research is the need to better understand how burnout progresses (Taris et al., 2005), particularly in contexts of extensive and non-continuous workdays (shifts), emphasizing relationships with other psycho-social variables. The theoretical model underpinning the SBI (Gil-Monte, 2005) may contribute information in this regard, and thus it is recommended that longitudinal studies be performed, analyzing empirically the antecedent-consequence relationship between the dimensions of the questionnaire and among these their antecedents and consequences.

\section{References}

Amelsvoort, L. G. (2004). Impact of one year of shift work on cardiovascular disease risk factors. Journal of Occupational and Environmental Medicine, 46, 699-706.

Baumeister, R. F., Stillwell, A. M., \& Heatherton, T. F. (1994). Guilt: An interpersonal approach. Psychological Bulletin, 115, 243-267.

Bakker, A. B., Demerouti, E., T. W., Taris, W., Schaufeli, W. B., \& Shreurs, P. J. G. (2003). A multigroup analysis of the job demands-resourcesmodel in four home care organizations. International Journal of Stress Management, 10, 16-38.

Bakker, A. B., Le Blanc P. M., \& Schaufeli W. B. (2005). Burnout contagion among intensive care nurses. Journal of Advanced Nursing, 51, 276-287.

Bekker, M. H. J., Croon, M. A., \& Bressers, B. (2005). Childcare involvement, job characteristics, gender and work attitudes as predictors of emotional exhaustion and sickness absence Work \& Stress, 19, 221-237.

Berger, A. M., \& Hobbs, B. B. (2006). Impact of shift work on the health and safety of nurses and patients. Clinical Journal of Oncology Nursing, 10, 465-471.

Brewer, E. W., \& Clippard, L. F. (2002). Burnout and job satisfaction among student support services personnel. Human Resource Development Quarterly, 13, 169-186.

Collins, V. A. (2000). A meta-analysis of burnout and occupational stress. Dissertation Abstracts International: Section B. Sciences and Engineering, 60, 4.942.

Cooper, C. L., Dewe, P., \& O’Driscoll, M. P. (2001). Organizational stress: A review and critique of theory, research, and applications. London: Sage.

Cox, T., Griffiths, A., \& Rial-González, E. (2000). Research on workrelated stress. European Agency for Safety and Health at Work. Luxembourg, Office for Official Publications of the European Camminities.

Eagly, A. H., \& Chaiken, S. (1993). The psychology of attitudes. Fort Worth, TX: Harcourt Brace Jovanovich.

Ekstedt, M., \& Fagerberg, I. (2005). Lived experiences of the time preceding burnout. Journal of Advanced Nursing, 49, 59-67.

Farber, B. A. (2000). Treatment strategies for different types of teacher burnout. Journal of Clinical Psychology, 56, 675-689.

Figueiredo-Ferraz H., Gil-Monte P. R., Grau-Alberola E., Llorca-Pellicer M., \& García-Juesas J. A. (2013). Influence of some psychosocial factors on mobbing and its consequences among employees working with people with intellectual disabilities. Journal of Applied Research in Intellectual Disabilities, 25, 455-63.

Gil-Monte, P. R. (2002). Influencia del género sobre el proceso de desarrollo del síndrome de quemarse por el trabajo (burnout) en profesionales de enfermería. Psicologia em Estudo, 7, 3-10.

Gil-Monte, P. R. (2005). El sindrome de quemarse por el trabajo ("burnout"). Una enfermedad laboral en la sociedad del bienestar. Madrid: Pirámide. 
Gil-Monte, P. R. (2012). Influence of guilt on the relationship between burnout and depression. European Psychologist, 17, 231-236.

Gil-Monte, P. R., Figueiredo-Ferraz, H., \& Valdez, H. (2013). Factor analysis of the Spanish Burnout Inventory among Mexican prison employees. Canadian Journal of Behavioural Science, 45, 96-104.

Gil-Monte, P. R., \& Olivares, V. (2011). Psychometric properties of the Spanish Burnout Inventory in Chilean professionals working to physical disabled people. Spanish Journal of Psychology, 14, 441-451.

Gil-Monte, P. R., Peiró, J. M., \& Valcárcel, P. (1998). A model of burnout proces development: An alternative from appraisal models of stress. Comportamento Organizacional e Gestão, 4, 165-179.

Gil-Monte, P. R., Valcárcel, P., \& Zornoza, A. (1995): Role stress: Burnout antecedent in nursing professionals. En J.M. Peiró, F. Prieto, J. L. Melia, y O. Luque (Eds.), Work and Organizational Psychology: European contributions of the nineties (pp. 77-87). Hove: Erlbaum (UK) Taylor \& Francis.

Glazer, S. (2005). Six of one, half a dozen of the other: problems with working fixed and rotating shifts international. Journal of Stress Management, 12, 142-163.

Gregersen, S., Kuhnert, S., Zimber, A., \& Nienhaus, A. (2010). Führung und Gesundheit - Zum Stand der Forschung. Das Gesundheitswesen, 73, 3-12.

Hochwälder J., \& Bergsten-Brucefors, A. (2005). Psychological empowerment at the workplace as a predictor of ill health. Personality and Individual Differences, 39, 1237-1248.

International Labor Organization (1991). International Labour Conference 76 (Report V). Ginebra: International Labour Office.

Iverson, D. R., Olekalns, M., \& Erwin, J. P. (1998) Affectivity, organizational stressors and absententism: a causal model of Burnout and its consequences. Journal of Vocational Behavior, 52, 1-23.

Jawahar, I. M., Stone, T. H., \& Kisamore, J. L. (2007). Role conflict and burnout: The direct and moderating effects of political skill and perceived organizational support on burnout dimensions. International Journal of Stress Management, 14, 142-159.

Jenaro, C., Flores, N., \& Arias, B. (2007). Burnout and coping in human service practitioners. Professional Psychology: Research and Practice, 38, 80-87.

Kahn, R. L., Wolfe, D. M., Quinn, R. P., Snoek, J. D., \& Rosenthal, R. A. (1964). Organizational stress: Studies in role conflict and ambiguity. Oxford: Wiley.

Kokkinos, C. M. (2007). Job stressors, personality and burnout in primary school teachers. British Journal of Educational Psychology, 77, 229-243.

Lambert, V. A., \& Lambert, C. E. (2001). Literature review of role stress/ strain on nurses: An international perspective. Nursing \& Health Sciences, 3, 161-172.

Lee, R. T., \& Ashforth, B. E. (1996). A meta-analytic examination of the correlates of the three dimensions of job burnout. Journal of Applied Psychology, 81, 123-133.

Lepine, J. A., Podsakoff, N. P., \& Lepine, M. A. (2005). A meta-analytic test of the challenge stressor-hindrance stressor framework: An explanation for inconsistent relationships among stressors and performance. Academy of Management Journal, 48, 764-775.

Levey, R. E. (2001). Sources of stress for residents and recommendations for programs to assist them. Academic Medicine, 76, 142-150.

López, B., Osca, A., \& Rodríguez, M. (2008). Estrés de rol, implicación con el trabajo y burnout en soldados profesionales españoles. Revista Latinoamericana de psicología, 40, 293-304.

Maslach, C. (1982). Burnout: The cost of caring. New York: Prentice Hall Press.

Maslach, C. (2003). Job burnout: New directions in research and intervention. Current Directions in Psychological Science, 12, 189-192.

Maslach, C., Schaufeli, W., \& Leiter, M. (2001). Job burnout. Annual Review of Psychology, 52, 397-422.

Mohr, A. T., \& Puck, J. F. (2007). Role conflict, general manager job satisfaction and stress and the performance of IJVs. European Management Journal, 25, 25-35.
Moreno-Jiménez, B., \& Garrosa, E. (2009). Globalización y riesgos laborales emergentes. Ciencia y Trabajo, 32, 31-33.

Nunnaly, N.C. (1978). Psychometric theory. Nueva York: McGraw-Hill.

Olson, E. J., Drage, L. A., \& Auger, R. R. (2009). Sleep deprivation, physician performance, and patient safety. Chest, 136, 1389-1396.

Örtqvist, O., \& Wincent, J. (2006). Prominent consequences of roles stress: A meta-analytic review. International Journal of Stress Management, 13, 399-422.

Osca, A., González-Camino, G., Bardera, P., \& Peiró, J. M. (2003). Estrés de rol y su influencia sobre el bienestar psíquico y físico en soldados profesionales. Psicothema, 15, 54-57.

Paine, W. S. (1982). The burnout syndrome in context. In J. W. Jones (Ed.), The burnout syndrome: Current research, theory, interventions (pp. 1-29). Park Ridge, II: London House Press.

Papastylianou, A., Kaila, N., \& Polychronopoulos, M. (2009). Teachers' burnout, depression, role ambiguity and conflict. Social Psychology of Education, 12, 295-314.

Parker, P. A., \& Kulik, J. A. (1995). Burnout, selfand supervisor-related job performance, and absenteeism among nurses. Journal of Behavioral Medicine, 18, 581-599.

Peeters, M. C. W., Montgomery, A. J., Bakker, A. B., \& Schaufeli, W. B. (2005). Balancing work and home: How job and home demands are related to burnout. International Journal of Stress Management, 12, 43-61.

Petitta, L., \& Vecchione, M. (2011). Job burnout, absenteeism, and extra role behaviors. Journal of Workplace Behavioral Health, 26, 97-121.

Piko, B. F. (2006). Burnout, role conflict, job satisfaction and psychosocial health among Hungarian health care staff: A questionnaire survey. International Journal of Nursing Studies, 43, 311-318.

Pineles, S. L., Street, A. E., \& Koenen, K. C. (2006). The differential relationships of shame-proneness and guilt-proneness to psychological and somatization symptoms. Journal of Social and Clinical Psychology, 25, 688-704.

Posig, M., \& Kickul, J. (2003). Extending our understanding of burnout: Test of an integrated model in nonservice occupations. Journal of Occupational Health Psychology, 8, 3-19.

Price, D. M., \& Murphy, P. A. (1984). Staff burnout in the perspective of grief theory. Death Eucation, 81, 47-58.

Radha, R. (2007). Indian model of executive burnout. Vikalpa, 32, 23-38.

Rauchenzauner, M., Ernst, F., Hintringer, F., Ulmer, H., Ebenbichler, C. F., Kasseroler, M. T., \& Joannidis, M. (2009). Arrhythmias and increased neuro-endocrine stress response during physicians' night shifts: a randomized cross-over trial. European Heart Journal, 30, 2606-2613.

Rizzo, J. R., House, R. J., \& Lirtzman, S. I. (1970). Role conflict and ambiguity in complex organizations. Administrative Science Quarterly, $15,150-163$.

Schaufeli, W. B. (2007). Burnout in health care. In P. Carayon (Ed.), Handbook of human factors and ergonomics in health care and patient safety (pp. 217-232). Mahwah, NJ: Lawrence Erlbaum.

Schaufeli, W. B., Bakker, A. B., Heijden, F., \& Prins, J. T. (2009). Workaholism, burnout and well-being among junior doctors: The mediating role of role conflict. Work \& Stress, 23, 155-172.

Schaufeli, W. B., Bakker, A. B., \& Van Rhenen, W. (2009). How changes in job demands and resources predict burnout, work engagement, and sickness absenteeism. Journal of Organizational Behavior, 30, 893-917.

Schwab, R. L., Jackson, S. E., \& Schuler, R. S. (1986). Educator burnout: Sources and consequences. Educational Research Quarterly, 10, 14-30.

Shinan-Altman, S., \& Cohen, M. (2010). Nursing aides' attitudes to elder abuse in nursing homes: The effect of work stressors and burnout. The Gerontologist, 49, 674-684.

Shirom. A. (2009). Acerca de la validez del constructo, predictores y consecuencias del burnout en el lugar de trabajo [On the construct validity, predictors, and consequences of burnout at work]. Ciencia \& Trabajo, 11, 44-55.

Tangney, J. P., Stuewig, J., \& Mashek, D. J. (2007). Moral emotions and moral behavior. Annual Review of Psychology, 58, 345-372.

Taris, T. W., Le Blanc, P. M., Schaufeli W. B., \& Schreurs, P. J. (2005). Are there causal relationships between the dimensions of the Maslach 
120 Víctor E. Olivares-Faúndez, Pedro R. Gil-Monte, Luis Mena, Carolina Jélvez-Wilke, Hugo Figueiredo-Ferraz

Burnout Inventory? A review and two longitudinal tests. Work \& Stress, 19, 238-255.

Toppinen-Tanner, S., Ojajärvi, A., Väänänen, A., Kalimo. R., \& Jäppinen (2005). Burnout as a Predictor of Medically Certified Sick-Leave Absences and Their D. Behavioral Medicine, 31, 18-27.

Tops, M., Boksem, M. A., Wijers, A. A., Van Duinen, H., Den Boer, J. A., Meijman, T. F., \& Korf, J. (2007). The psychobiology of burnout: re there two different syndromes? Neuropsychobiology, 55, 143-150.

Tunc, T., \& Kutanis, R. O. (2009). Role conflict, role ambiguity, and burnout in nurses and physicians at a university hospital in Turkey. Nursing and Health Sciences, 11, 410-416.

Vanheule, S., Lievrouw, A., \& Verhaeghe, P. (2003). Burnout and intersubjectivity: A psychoanalytical study from a Lacanian perspective. Human Relations, 56, 321-339.

Zellars, K. L., Perrewe, P. L., \& Hochwarter, W. A. (1999). Mitigating burnout among high-NA employees in health care: What can organizations do? Journal of Applied Social Psychology, 29, 2250-2271. 